\section{Journal of Sciences and Engineering}

Vol. 1, $\mathrm{N}^{\circ}$ 1, 2017
A publication of

\section{CINCADER}

Centre of Research and Training for

Regional Development

Online at www.journals.cincader.org

\author{
Methods used to determine the zeta potential of \\ colloids in wastewater \\ Jhonny Valverde Flores ${ }^{\mathrm{a}, \text { * }}$ \\ a Institute of Sciences and Engineering, Centre of Research and Training to the Regional Development (CINCADER). \\ Lima 39, Peru. \\ ihoval1@yahoo.es
}

\begin{abstract}
Resumen
El agua es el elemento vital en la vida cotidiana del hombre y el valorar su tratamiento, es buscar prever la sostenibilidad del planeta y preservar la vida humana. El estudio es descriptivo y comparativo. El objetivo fue proponer el método más apropiado para la determinación del potencial zeta de los coloides en aguas residuales. El procedimiento operacional, exige el conocimiento de más parámetros relacionados, lo cual implica mayores análisis y por ende mayor inversión económica. Los métodos descritos son los: Electroforesis, Electroósmosis, Potencial de flujo y potencial de sedimentación. De los cuatro métodos para la determinación de potencial zeta en aguas residuales se concluye que el método de la electroforesis, es el más usado hasta la actualidad, el cual es usado en diferentes áreas en mayor o menor escala, como en la aplicación de soluciones con diferentes tipos de contaminante a diferencia de los otros métodos antes mencionados. La electroforesis cuenta con diseños variados de tal manera que se pueda construir manualmente y ser aplicable desde experimentos pequeños con materiales más accesibles y fáciles de conseguir, permitiendo variar la inversión de construcción del equipo de acuerdo a la escala del trabajo en el que se quiere aplicar dicho método.
\end{abstract}

Palabras clave: Aguas residuales, Métodos de tratamiento, Potencial Zeta, Coloides

\begin{abstract}
Water is the vital element in the daily life of man and the value of his treatment is to look for the sustainability of the planet and to preserve human life. The study is descriptive and comparative. The objective was to propose the most appropriate method for the zeta potential determination of colloids in wastewater. The operational procedure requires the knowledge of more related parameters, which implies greater analysis and therefore greater economic investment. The methods described are: Electrophoresis, Electroosmosis, Flow potential and sedimentation potential. Of the four methods for the determination of zeta potential in wastewater it is concluded that the electrophoresis method is the most used until now, which is used in different areas in greater or lesser scale, as in the application of solutions with different types of pollutant, unlike the other methods mentioned above. The electrophoresis has varied designs in such a way that it can be built manually and be applicable from small experiments with more accessible and easy-to-get materials, allowing to vary the construction investment of the equipment according to the scale of the work in which it is to be applied this method.
\end{abstract}

Keywords: Wastewater, Treatment methods, Zeta Potential, Colloids 


\section{Journal of Sciences and Engineering}

Vol. 1, $\mathrm{N}^{\circ}$ 1, 2017

Copyright @ 2017, CINCADER.

ISSN 2523-9503
A publication of CINCADER

Centre of Research and Training for

Regional Development

Online at www.journals.cincader.org

\section{Introduction}

Currently, water is the most important and essential resource in human life, the lack of this vital element is bringing great global concern, with its eagerness to maintain, conserve and treat it for reuse, as it is being polluted in a manner indiscriminate by different types of anthropogenic activities. That is why the search for new technologies and methods appear to maximize their use with the treatment and reuse of wastewater (Sette, 1990). As is the case of colloids, which are very fine particles with a diameter between $10^{-6} \mathrm{~m} \mathrm{and}$ $10^{-9} \mathrm{~m}$., Which has great chemical stability, which makes it difficult to eliminate wastewater, increasing the costs of treatments, and one of the most significant characteristics are its high electric charge (potential z). The vast majority of substances are colloidal and are present in all processes, activities, food, waste, etc. and if not treated properly, they will continue to represent a danger to our resources. Some pollutants of greater size and lower degree of stability can be treated through flocculation, achieving the agglutination and sedimentation in a matter of hours, behavior that the colloids do not follow. Consequently, the potential $z$ is the electric charge that a substance possesses, according to its nature, the determination of this, will allow to manipulate the contaminant through different methods and obtain a greater degree of effectiveness.

Some authors such as Moser and Wiech, (1968), in their patent "Zeta Potential Flowmeter", disclose the design and operation of a flow meter that allows the displacement of a fluid, to determine the electrokinetic Zeta potential. This equipment has a highly sensitive flow meter, since it can register and measure very low rates, such as $0.3 \mathrm{~mL} /$ month. The equipment has a flow meter with non-porous glass beads in the range of 25 microns to 100 microns contained in a tubular Teflon cell. The pearls occupy a space of $64 \%$ of the cell. It also has electrodes, made of platinum mesh, an input resistance electro voltmeter, to measure the potential between the electrodes and nuts to hold both ends of the tubular cell. This equipment is light and compact, easy to build and repair.

Also in their study Culkin, J. (1986), in his patent determines the zeta potential of the particles in suspension, besides providing a power oscillator, to produce an unstable electric field between the electrodes, this causes the acceleration of the particles in suspension, which produces a force, which can be used as electrical current through a mechanical resonator. It should be noted that the voltage supplied to the electrodes has a frequency range of 0 to $50 \mathrm{KHz}$ so that the acceleration of the particles in the cell is considered as homogeneous. The acceleration of the particles generates an electric field by means of a force that acts to move the layer furthest away from the particle, observing a net migration of particles in only one direction, leaving only the liquid in the opposite direction.

Subsequently David et al. (1991), in their patent shows a new procedure for measuring the zeta potential in a laminar flow of a liquid containing particulate material in suspension. The method consists in regulating the flow rate and the constant electric tension, this allows to achieve the migration of the particles through the electrophoretic speed, taking into account also the density of the electrical tension and the distance between the particles. The zeta potential can be determined using a certain formula. It also has a cell that has molybdenum or platinum electrodes placed under a special colloidal microscope.

Jayaweera et al. (1994) in their patent determine the zeta potential of the particles at high temperatures in different thermal and thermochemical processes. This equipment works with electrolyte, which is pumped into a loop containing a tube of thermo resistant material that is controlled by temperature controls and thermocouples that detect the temperature at both ends through a Rulon (poly tetrafluoroethylene, which includes a resistant load such as fiberglass, quartz, asbestos, mica, etc.) and to generate the flow potential the electrolyte is passed through the colloids to study, through the Rulon. The flow potential generated by the Rulon column is measured with an electrometer.

Aoki Hidemitsu, (2000), in its patent determines the zeta potential of suspended particles, which are subjected to an electric field, which causes the particles to have a tendency to generate bubbles, to achieve cleanliness or rinsed in a liquid medium. This equipment is composed of a cell that contains electrodes separated from each other divided into two parts, with different signs of charge (one positive and one negative). At a small distance from each electrode, bubble barriers generated in the solution are placed, this 


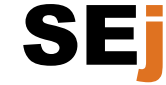

Vol. 1, N 1, 2017

\section{Journal of Sciences and Engineering}

A publication of CINCADER

Centre of Research and Training for

Regional Development

Online at www.journals.cincader.org

Copyright @ 2017 , CINCADER.

ISSN 2523-9503

is achieved by making holes in the location of the electrodes so that the bubbles can be released, the first bubble barrier is directed to the negative electrode and similarly the second electrode is directed to the positive electrode; both act as blocking barriers. The first barrier bubble membrane has the property of blocking bubbles generated in the solution in the vicinity of the positive electrode that move towards the negative electrode. The second barrier bubble membrane has the property of blocking the bubbles generated in the solution in the vicinity of the negative electrode that move towards the positive electrode. This allows the bubbles do not interact in a middle zone, however, this does not prevent the passage of ions, because the first and second barriers have the property of allowing the ions of the first and second barrier bubbles. It implies that the flow of an electric current will depend on the tension to which the liquid medium is subjected.

Sides et al. (2008) in their patent determine the zeta potential of surfaces by varying the transmission of the current or flow potential near the surfaces. The zeta potential of a rotating disc can be measured between two electrodes, where an electrode is located on the axis of rotation of the disk distance and attached to the disk surface of about $5 \%$ of the radius of the disk with the other electrode away from the distance to the disk of approximately ten times the radius of the disk.

Lin et al. (2014) in their patent provides a method to manufacture a biodegradable carrier, which allows to vary the zeta potential according to what required and the particle size. The method consists in the preparation of a solution in which a biodegradable macromolecule with a certain electrical characteristic is immersed; Next, another solution with an electrical characteristic different from the first one is prepared, in order that both solutions are mixed. Taking into account that both electric charges of each solution are opposite in order to form an electric field in which the desired zeta potential can be determined by the force of attraction between the different electrical properties. Next, according to the particle size, the number of moles of both macromolecules is proportionally adjusted. The size of the particle correlates positively with the number of moles of the solid in suspension, to adopt the role of biodegradable carrier with the desired particle size. Finally, the mixture is filtered to obtain biodegradable support. In conclusion, the zeta potential and the particle size of the biodegradable material, if it can be adjusted according to the zeta potential configuration of the first biodegradable carrier and then adapting the concentration of the mixture, to form the biodegradable carrier with the particle size biodegradable, it can be applied to different substances, which vary in their physical and chemical properties.

Kakadjian et al. (2014) in its patent shows a method to modify the surfaces of metal and particles in terms of their physical and chemical properties, through the circulation of a fluid by means of pumping in a certain deposit. The fluid has certain concentrations of substances such as amine, ether and additionally if a solvent component is preferred, they act as a coating to achieve the modification of properties on surfaces and residual oil particles adhering thereto. The coating is circulated in such a way that it comes into contact with the metal surface and the residual oil particles.

Colloids are generally irreversible particles, that is to say very stable (diurnal) thermodynamically, that is, they have a slow aggregation. Therefore, these are attributed to the pollution of wastewater and the types of treatments are basically aimed at reducing stability, ie converting them to what is called reversible colloids of rapid aggregation (expired).

Aguilar et al. (2002) mentions that colloidal particles are those that have an electric charge, due to their movement by applying an electric field. The sign of this primary charge can be positive or negative, although most of the colloids in the wastewater develop a negative primary charge. [...] this load is a function of the particle and the medium in which it is dissolved. [...] The sign and magnitude of the charge is frequently affected by the $\mathrm{pH}$ and the ionic content of the aqueous phase. [...] It is conformed by a rigid solution and diffuse layer. That are formed from the surface of the particle, there is a layer of ions absorbed within the limits of the solid of the same sign of the colloidal particle, and a layer of ions of opposite sign, called contractions, with a number of electric charges less than the first ones, which are strongly retained by electrical attraction within what is called the rigid dissolution frontier. On the other hand, the electrostatic 
SE

Vol. 1, $\mathrm{N}^{\circ}$ 1, 2017

\section{Journal of Sciences and Engineering}

A publication of

\section{CINCADER}

Centre of Research and Training for

Regional Development

Online at www.journals.cincader.org

Copyright (c) 2017, CINCADER.

ISSN 2523-9503

attraction of the contractions towards the surface of the particles, gives rise to a concentration gradient, in such a way that the electrical agitation of these ions, can cause these ions to diffuse, from the surface of the particle towards the main mass of the solution. This is called diffusion.

The type of particles, according to their behavior in contact with water, is classified into: a) hydrophilic or lipophilic colloids (react with water) and b) hydrophobic or lyophobic colloids (do not react with water). The stability of the colloids is summarized in the different forces that interact between the particles, among them we have the force of London Van der Waals, electrical interaction, hydration force, hydrophobic hydration, etc. (Aguilar et al., 2002).

The zeta potential, expressed under the letter $\zeta$, describes the intensity of the static electric field of the double layer at the boundary between the grain and the fluid (cutting plane). The values of the zeta potential can be seen in the following table.

Table 1. Values of the zeta potential and characteristics of the suspension

\begin{tabular}{cl}
\hline Values of Zeta Potential & \multicolumn{1}{c}{ Characteristics of the suspension } \\
\hline+3 a $0 \mathrm{mV}$ & Maximum agglomeration and precipitation \\
$-1 \mathrm{a}-5 \mathrm{mV}$ & Excellent agglomeration and precipitation \\
$-5 \mathrm{a}-10 \mathrm{mV}$ & Good agglomeration and precipitation \\
$-\mathbf{1 1} \mathrm{a}-20 \mathrm{mV}$ & Beginning of the agglomeration (aggregates of 2 \\
& to 100 colloids) \\
$-21 \mathrm{a}-30 \mathrm{mV}$ & Light stability \\
-31 a $-40 \mathrm{mV}$ & Without aggregates. Average stability \\
$-41 \mathrm{a}-50 \mathrm{mV}$ & Good stability \\
$-51 \mathrm{a}-60 \mathrm{mV}$ & Very good stability \\
-61 a $-80 \mathrm{mV}$ & Excellent stability \\
$-81 \mathrm{mV}$ y en adelante & Maximum stability \\
\hline
\end{tabular}

Source: Physico-chemical treatment of wastewater: coagulation-flocculation, (Aguilar et al., 2002)

\section{Electric field}

The electric field, is a vector that describes the condition in the space created by the system of point charges, by moving the witness charge, q0 from one field to another, we can determine $E$ in all points of space (except for the one occupied by a load, q). The electric field $\mathrm{E}$, is therefore a vector function of the position. The force exerted on a witness charge $\mathrm{q} 0$ at any point is related to the electric field at that point.

$$
\mathrm{F}=\mathrm{q} 0 . \mathrm{E}
$$

\section{Materials and Methods}

The investigation was carried out with the following stages:

Stage 1: Identification of methods. Information was sought from international patent offices.

Stage 2: Translation of patents. The methods were identified and translated from English to Spanish).

Stage 3: Evaluation of methods. The methods for the determination of the $z$ potential of colloids in wastewater were evaluated.

Stage 4: Method selection. Four methods were selected: Electrophoresis, Electrosmosis, Flow potential and sedimentation potential. 


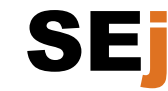

Vol. 1, No 1, 2017

\section{Journal of Sciences and Engineering}

Copyright (C) 2017, CINCADER.

ISSN 2523-9503
A publication of

\section{CINCADER}

Centre of Research and Training for

Regional Development

Online at www.journals.cincader.org

\section{Results}

\section{Methods to determine the zeta potential in colloids}

\section{Electrophoresis}

It is a technique of separation of molecules in a mixture of application of an electric field. Dissolved molecules move or migrate in an electric field at a rate determined by their charge: mass ratio. (Cruces, 1998)

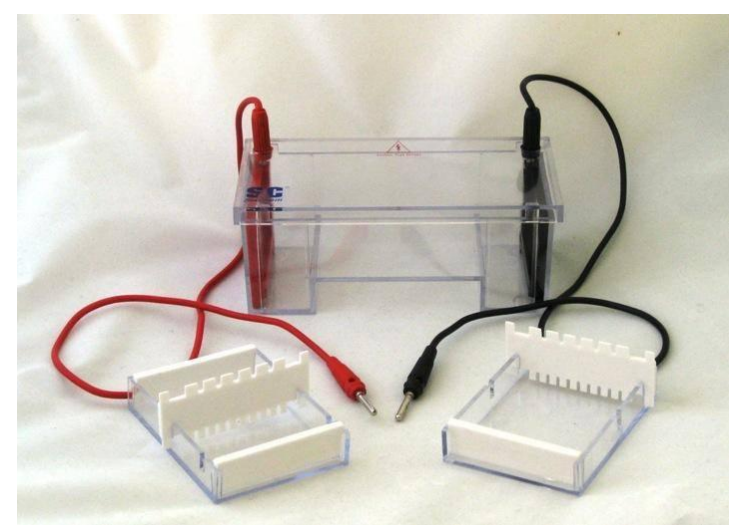

Figure 1. Electrophoresis equipment

Electrophoresis consists of the migration of charged molecules through a medium by the action of an electric field. The electrophoretic techniques have as a driving force that generated by the electric field and as a retarding force that the medium can exert against the movement [...]. Both the direction and the migration speed of each molecule depend on the sign and intensity of the charge it presents, as well as the characteristics of the medium in which it migrates (Roca et al., 2004).

$$
v=\frac{Q * \partial E}{6 * \partial \sigma * \partial r * \partial x}
$$

Where:

E: Electric field strength

Q: Colloid electric charge

r: Colloid radius (spherical)

$\mathrm{x}$ : Viscosity of the medium

$\mathrm{v}$ : Speed of the molecule

\section{Procedure for measuring the zeta potential}

1) When you start, measure the conductivity.

2) Apply the electric field through the electric field generator. Most are capable of generating electric current of $0-15 \mathrm{~mA}$ and $0-500 \mathrm{~V}$.

3) Reverse the electric field to avoid polarization and electroosmosis. It is recommended to use Uzgiris cells, which avoid the electroosmotic effect.

4) Measure the movement of the particles, for which use will be made of a buffer and an electrophoretic support. 


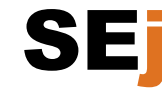

Vol. 1, N 1, 2017

\section{Journal of Sciences and Engineering}

Copyright (C) 2017, CINCADER.

ISSN 2523-9503
A publication of

\section{CINCADER}

Centre of Research and Training for

Regional Development Online at www.journals.cincader.org

5) Observe the direction in the + or - direction

- Particles + move towards -

- particles - move towards +

- Determine the speed through the amplitude. Get speed from the change in the frequency of movement of the particles.

The movement of the particles causes a double change.

Frequency $\rightarrow$ Mobility $\rightarrow$ Zeta potential.

Mobility

$$
\mu=\frac{\Delta \omega \lambda_{0}}{4 \pi n E(\theta / 2) \sin [(\theta / 2)+\xi]}
$$

Zeta potential

$$
\mu=\frac{2 \xi \varepsilon}{3 \eta_{0}} f(k a)
$$

Where:

$\mu$ : Electrophoretic mobility

$\Delta \omega$ : Doppler frequency change

$\lambda \_0$ : Laser wavelength

$\mathrm{n}$ : average refractive index

$\mathrm{E}$ : Electric field strength

$\theta$ : Angle between incident and scattered light

$\xi$ : Zeta Potential

$\varepsilon$ : Dielectric permittivity

$\eta 0$ : Average viscosity

$f(k a)$ : Relationship between the radius of the particle and the double layer

6) $f(k a)$ is a function of how thin or thick the double layer is. The variability of the double layer is a function of the concentration of the medium electrolyte, these being in an inversely proportional relationship, since the layer is compressed by increasing the concentration of the electrolyte, thus decreasing the stability of the colloidal particle. 


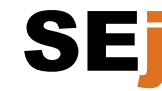

Vol. 1, No 1, 2017

\section{Journal of Sciences and Engineering}

Copyright @ 2017, CINCADER.

ISSN 2523-9503
A publication of

\section{CINCADER}

Centre of Research and Training for

Regional Development Online at www.journals.cincader.org

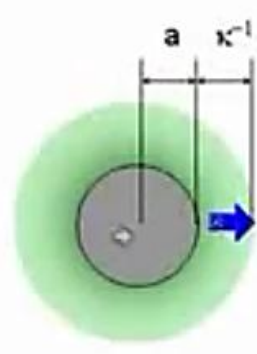

Huckel $F(k a)=1.0$

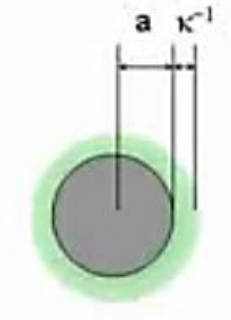

thin double layer Smoluchowski $F(x a)=1.5$ ка $\gg 1$

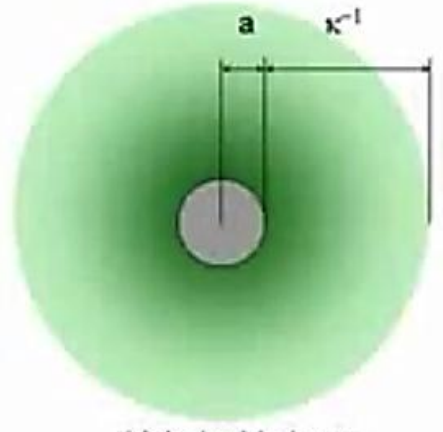

thick double layer

ка $\ll 1$

Figure 2: Double layer of the colloids according to their expansion radius Source: Horiba Company

Where:

a: Particle radius

$k^{\wedge}(-1)$ : Length of the double layer

7) Place the instrument in a clean environment on a surface without vibration.

8) Check the dispersion liquids, since these ensure compatibility between the medium and the cell.

9) Check the operation of the cells and that they are clean. Control the temperature.

10) Perform the inspection of samples, looking for sedimentation, if this is visible after the measurement, it is questionable to try to eliminate the dilution.

11) Be sufficiently homogeneous and stable for the indicated time and temperature range.

12) The value of electrophoretic mobility, must be obtained by several operators and a demonstrated rigor.

\section{Electroosmosis (Dissolution flow)}

Electro-osmosis is an important electrokinetic effect that can be used for particle handling and separation, as well as flow pumping and mixing improvement applications. An advantage of electroosmosis is seen in the design of electro-osmotic pumps. Electroosmosis is often accompanied by electrophoresis.

"The electroosmosis is observed when an electric field is applied in two electrodes that are placed side by side". (Karniadakis, 2006) 


\section{Journal of Sciences and Engineering}

Copyright @ 2017, CINCADER.

ISSN 2523-9503
A publication of

\section{CINCADER}

Centre of Research and Training for

Regional Development

Online at www.journals.cincader.org

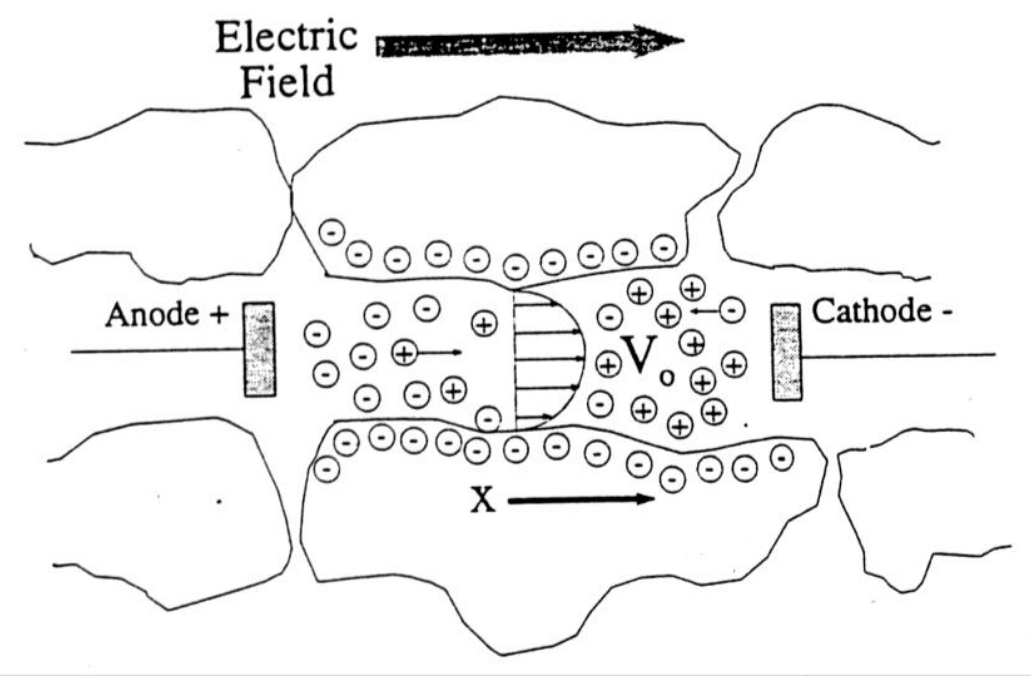

Figure 3. Movement of Cations in a Soil Pore by Electro-Osmosis Source: http://www4.uwm.edu/radon/yoon/

In this separation method, unlike electrophoresis, the electric field is applied to the fluid, which creates a current that moves the particles towards the electrodes generating a long-range circulation. The relative movement of a liquid with respect to a charged surface, under the action of an electric field is also known as electroosmotic flow (Cruces, 1998). The procedure using this method is as follows:

1) In a cell, the electrodes are placed on the surface of the cell, whose measurements will be based on the size of the electrodes to be used (as a reference, they can be $5 \mu \mathrm{m}$ and $100 \mu \mathrm{m}$ ) and a circular electroosmotic flow is applied throughout of the electrodes on the surface.

2) The electroosmotic flow will depend on the composition of the capillary (cell) and the nature of the solution inside the capillary. The capillary can be made of glass, Teflon or fused silica, which often influences, to acquire a greater load and facilitate the ionization process of the particles.

3) When applying an electric field, the mobile cation layer moves towards the cathode, but if we take into account that the cations are already solvated, then they will drag the whole of the solution with it, finally achieving the electroosmotic flow.

4) The fluid used as a circulation medium for the particles circulates through the cell, induced by a voltage to the electrodes and the ions, remain aligned due to the voltage applied to the electrodes, in such a way that a diffuse double layer is formed, which is usually thin.

5) Between the two layers, there is a cutting plane in which an electrical decompensation is created, which is the potential difference across the layers and is called the zeta potential $(\zeta)$ (Cruces, 1998)

$$
\zeta=4 \pi \delta e / \epsilon
$$

Where:

$\delta:$ Thickness of the diffuse layer

e: Load per unit of surface area

$\varepsilon$ : Dielectric constant of the buffer solution 


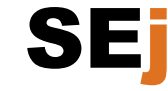

Vol. 1, $\mathbf{N}^{\circ}$ 1, 2017

\section{Journal of Sciences and Engineering}

Copyright @ 2017, CINCADER.

ISSN 2523-9503

6) This type of fluid is driven by an electric field, which implies that the flow profile will be almost flat, because the force that drives the fluid is distributed along the cell or capillary. This characteristic of electroosmosis is very important, since that indicates that the velocity of the solute at any point will be the same. However, this does not make it more efficient than electrophoresis, because unlike electrophoresis, the time it takes for the solute to travel along the cell directly affects both the efficiency and the resolution of the separation.
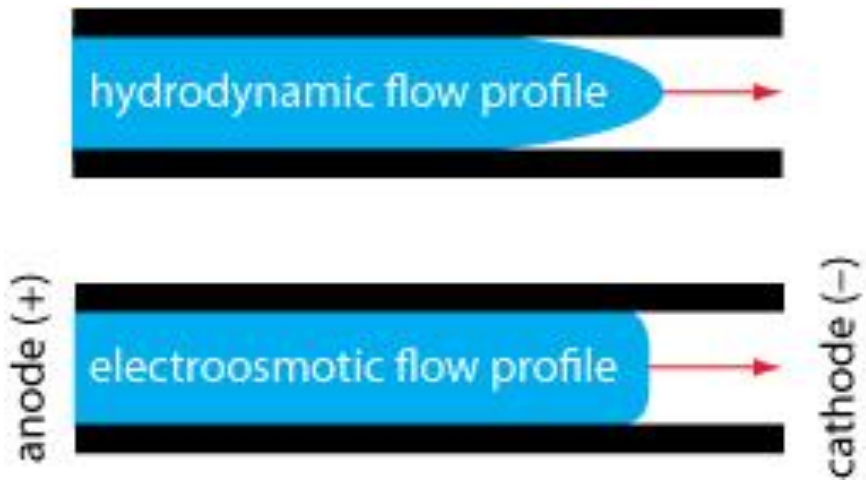

Figure 4: hydrodynamic flow profile vs. Electroosmotic flow profile

Source: Harvey (2016)

7) The velocity of the electroosmotic flow is given by:

$$
V_{e o}=\mu_{e o} . E \mathrm{~cm}^{2} / V \cdot \mathrm{seg}
$$

8) On the other hand, it is also necessary to calculate the electroosmotic mobility, which depends on the zeta potential and the type of buffer used.

$$
\mu_{e o}=\zeta \epsilon / 4 \pi \eta
$$

Where:

$\zeta$ : Zeta potential

$\varepsilon$ : Dielectric constant of the buffer solution

$\eta$ : electroosmotic mobility

$\mu \_$eo: Electroosmotic mobility

Experimentally, the electroosmotic mobility is influenced by the electrophoretic medium, dielectric constant, $\mathrm{pH}$, concentration, viscosity, but is independent of the applied electric field.

$$
\mu_{e o}=v_{e o} / E=L_{D} \cdot L_{T} / t_{e o} . V
$$

9) To obtain good results when starting the operation, the electroosmotic flow must remain neutral, for this it must have a value equivalent to zero, called a neutral marker. This is a way to maintain the electroosmotic flow constant. This will be achieved, through the use of a neutral solute, which will move at the same speed of the electroosmotic flow, in such a way that by measuring the time and length displaced, it will allow to know the electroosmotic flow. 10) The values that electroosmotic mobility constantly takes, is in the range of $10^{-5}-10^{-4} \mathrm{~cm}^{2} / V$. seg. 
SE

Vol. 1, $\mathrm{N}^{\circ}$ 1, 2017
Journal of Sciences and

Engineering

11) The added solute or also called electroosmotic marking, must be chosen so that it complies with a series of requirements, to guarantee accurate results. For which,

Cruces (1998) mentions:

- that is pure

- That is soluble in water

- that is neutral over a wide $\mathrm{pH}$ range

- that does not produce adsorption phenomena on the walls of the capillary

- that can be easily detected with any detection system at low concentrations.

The recommended or used generally are benzene, phenol, methanol, acetone, formamide, etc.

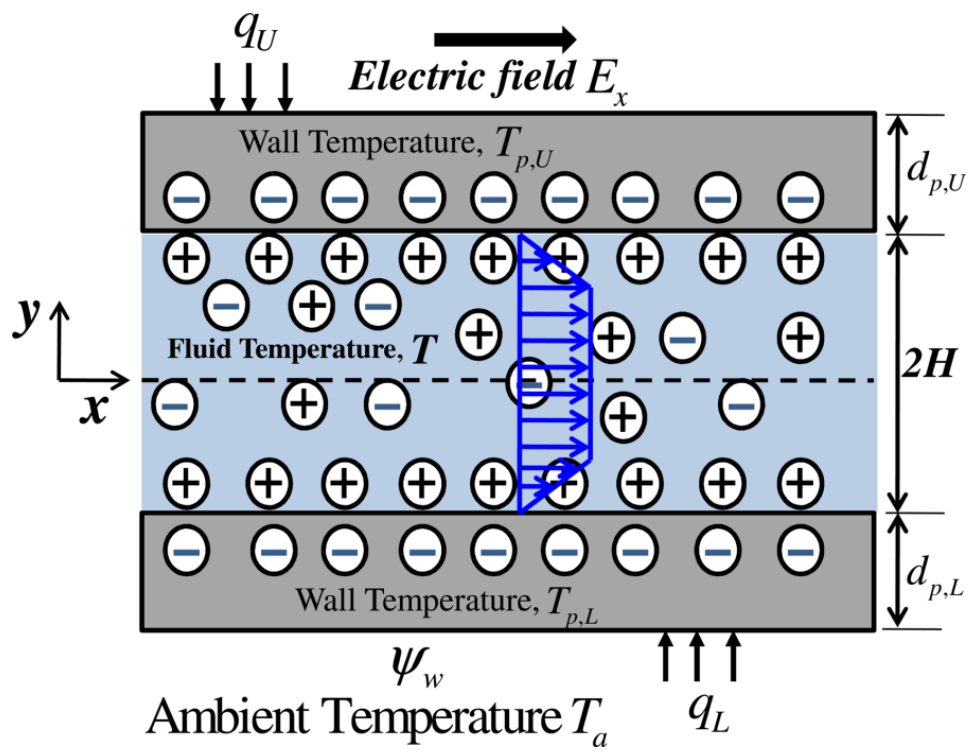

Figure 5: Behavior of the particles in the electroosmotic

\section{Sedimentation potential}

It is part of the considered electrokinetic movements. The movement of the particles induces a field. It allows to separate charged particles subjected to centrifugation, fact that produces an electric field (Fernández, 2006). In this method, we talk about the difference of potential of fall that occurs when subjecting a solution to a gravitational field. It is also known as the inverse of electrophoresis. 


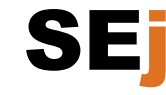

Vol. 1, $\mathbf{N}^{\circ}$ 1, 2017

\section{Journal of Sciences and Engineering}

Copyright @ 2017, CINCADER.

ISSN 2523-9503
A publication of

\section{CINCADER}

Centre of Research and Training for

Regional Development

Online at www.journals.cincader.org

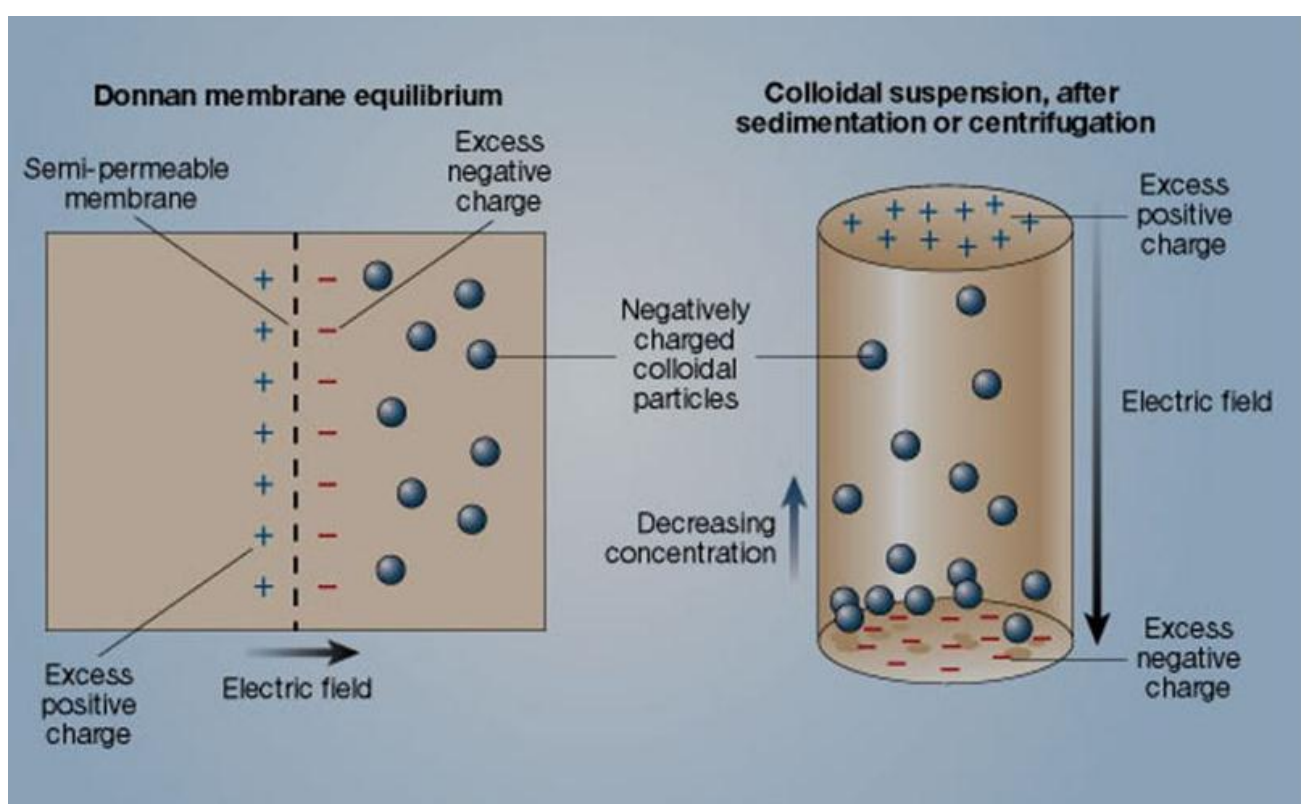

Figure 6: Sedimentation Potential

For this method, the smoluchowsky electrokinetic equation is applied

$$
E=\frac{P \varepsilon \zeta}{4 \pi \eta \lambda}
$$

In a solid and liquid medium, the values are constant, unlike $E$ and $P$, which vary, where $P$ is the difference in hydrostatic pressure, which is exerted on the solution inside the cell in the middle of the electrodes. This factor can be calculated as follows:

$$
P=\frac{W\left(\rho-\rho_{0}\right)}{A \rho}
$$

Where:

W: Weight of the particles in the solution

$\rho:$ Density of the solid

$\rho_{0}$ : Density of the liquid

A: Area of a straight section in the sedimentation tube

It should be noted, that all the factors are constant, for a certain system, except W; therefore, variations in the results of the sedimentation potential will be due specifically to the weight of the particles in the solution (W).

This method is the least used for the determination of the zeta potential, due to the amount of data that is needed, but nevertheless it is very useful to determine an infinity of electrokinetic parameters.

Finally, the formula used is given by:

$$
E=\frac{\zeta \varepsilon W\left(\rho-\rho_{0}\right) g}{4 \pi \eta \lambda A \rho}
$$

Where the units of measure for each factor, should be 
Vol. 1, N 1, 2017

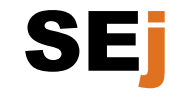

\section{Journal of Sciences and Engineering}

Copyright @ 2017, CINCADER.

ISSN 2523-9503
A publication of

\section{CINGADER}

Centre of Research and Training for

Regional Development

Online at www.journals.cincader.org

$$
\begin{aligned}
& \rho \mathrm{y} \rho_{0}: \mathrm{gr} / \mathrm{cc} \\
& \text { A: } \mathrm{cm}^{2} \\
& \lambda: \Omega^{-1} \cdot \mathrm{cm}^{-1} \\
& \varepsilon=\varepsilon_{\mathrm{r}} \\
& \eta: \text { poises } \\
& \mathrm{g}: \mathrm{cm} \cdot \mathrm{s}^{2} \\
& \text { W: gr }
\end{aligned}
$$

\section{Flow or current potential}

It is a procedure based on the circulation of a fluid through a capillary, which leads to an idea of pressure between the ends, which in turn generates a potential difference between both points. (Fernández, 2006)

$$
\frac{I \eta l}{p \varepsilon}=\frac{\zeta A}{4 \pi}
$$

Where:

I: Intensity of the flow of flow in the capillary

$\eta$ : Viscosity

$l$ : Package length of fibrous material

$\mathrm{p}$ : Pressure difference through the capillary

$\varepsilon$ : Electric constant of the liquid

$\zeta$ : Zeta potential

A: Capillary section area

The potential flow method has been commonly used for the determination of the zeta potential. It is applicable to different types of colloidal systems, even in fibrous materials. This method is the reverse of electroosmosis, since a hydrostatic pressure is applied through the fluid of a liquid. It is given as follows:

1) In a measuring cell (1), the water sample is placed, taking into account that the cell contains the electrodes.

2) An electrolyte solution is also required, which will be added to the cell through a tube from a container. (Referential volume 5 liters) connected to cell (1).

3 ) then, a variable nitrogen pressure is applied to the container containing the electrolyte and the cell (1), said pressure must be measured by a pressure transducer, which will subsequently be measured through a recorder.

4) Then, the potential difference between the electrodes of the cell (1) must be verified with a millivoltmeter, since a high precision in the measurement is required; information that is received through a recorder, product of the electrical signals emitted.

5) In addition, for the application of the formula, it is also required to measure the conductivity of the solution in cell (1), for which a conductivity meter was available.

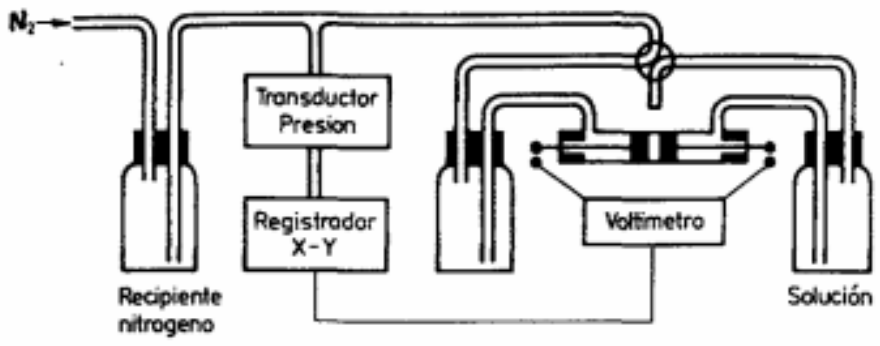




\section{Journal of Sciences and Engineering}

Vol. 1, $\mathrm{N}^{\circ} 1,2017$

Copyright (C) 2017, CINCADER.

ISSN 2523-9503

Figure 7: Design of apparatus for the determination of zeta potential through flow potential.

\section{Conclusions}

* From the evaluation of the 4 methods for the determination of zeta potential in wastewater, through the patent review, it was obtained that the electrophoresis method is the most used until now, since it can be used in different areas in greater or lesser scale, because it allows the application in solutions with different types of contaminants unlike the other methods mentioned above, because for these, the operational procedure requires knowledge of more related parameters which implies greater analysis and therefore greater economic investment.

* Electrophoresis allows the variation of the design of the equipment, in such a way that it can be built manually and be applicable from small experiments with more accessible and easy to obtain materials, allowing to vary the investment of construction of the equipment according to the scale of the work in which you want to apply that method.

\section{Acknowledgments}

We gratefully acknowledge to the Institute of Science and Engineering, Centre of Research and Training to the Regional Development, (In Spanish, Centro de Investigacion y Capacitacion para el Desarrollo RegionalCINCADER) for allowing us to share technical experiences.

\section{Reference}

Aguilar M.; Saez, J; Llorens,M; Soler, A; Ortuño, J. Tratamiento físico - químico del agua [en línea]. España: universidad de Murica, 2002 [Fecha de consulta: 28 septiembre 2016]. Disponible en: https://books.google.com.pe/books?id=8vIQBXPvhAUC\&printsec=frontcover\&hl=es\&source=gbs_ge_s

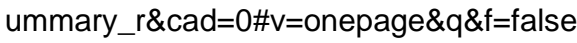

Cruces, Carmen. Electroforesis capilar. [En línea]. Universidad de Almería: Escobar. 1998. [Fecha de consulta: 28 septiembre 2016]. Disponible en:

https://books.google.com.pe/books?id=TUSWtthmCc0C\&printsec=frontcover\&dq=electroforesis\&hl=es\&sa $=\mathrm{X} \& \mathrm{ved}=0$ ahUKEwi0_8H9ppnYAhWERyYKHb7QAqcQ6AEILjAC\#v=onepage\&q=electroforesis\&f=fals $\mathrm{e}$

Electro-Osmosis. ELECTRO-OSMOTIC PULSING TECHNOLOGY LABORATORY. University of Wisconsin, Milwaukee. [Fecha de consulta: 28 septiembre 2017]. Disponible en:

http://www4.uwm.edu/radon/yoon/

Fernandez, Luis. Elementos de física para las ciencias de la vida [En línea]. Universidad de Oviedo (2006). [Fecha de consulta: 19 octubre 2017]. Disponible en:

https://books.google.com.pe/books?id=1vPGq0wXv-

UC\&pg=PA391\&dq=potencial+de+sedimentaci\%C3\%B3n\&hl=es\&sa=X\&ved=0ahUKEwjWybGz1OfPA hVEFR4KHQBeCLYQ6AEIJTAC\#v=onepage\&q=potencial\%20de\%20sedimentaci\%C3\%B3n\&f=false

Harvey, David. Electrophoresis. DePauw University. Analytical Chemistry 2.0. 2016. [Fecha de consulta: 28 septiembre 2017]. Disponible en:

https://chem.libretexts.org/Textbook_Maps/Analytical_Chemistry_Textbook_Maps/Map\%3A_Analytical_Ch emistry_2.0_(Harvey)/12_Chromatographic_and_Electrophoretic_Methods/12.7\%3A_Electrophoresis 


\section{SEj \\ Vol. 1, $\mathrm{N}^{\circ}$ 1, 2017 \\ Journal of Sciences and Engineering}

Copyright @ 2017, CINCADER.

ISSN 2523-9503
A publication of

\section{CINGADER}

Centre of Research and Training for

Regional Development

Online at www.journals.cincader.org

Karniadakis, George; Beskok, Ali; Aluru, Narayan. Microflows and Nanoflows: Fundamentals and simulation [En línea]. EE.UU: Springer (2006). [Fecha de consulta:19 octubre 2016]. Disponible en: https://books.google.com.pe/books?id=vDiLnJHSqvYC\&pg=PA272\&dq=electroosmosis\&hl=es\&sa=X\& ved=0ahUKEwiuwsahjefPAhVBVh4KHQkbBMgQ6AEIIDAB\#v=onepage \&q=electroosmosis\&f=false

Roca, Pilar; Oliver, Jordi; Rodriguez, Ana. Bioquímica: Técnicas y métodos [En línea].España: Hélice (2004).[Fecha de consulta: 10 octubre 2017]. Disponible en:

https://books.google.com.pe/books?id=hrd7v5YNo1UC\&pg=PA163\&dq=como+se+da+la+electroforesis\&hl $=e s \& s a=X \& v e d=0$ ahUKEwio8ouHm

fPAhWEGB4KHX1bDDsQ6AEIHzAA\#v=onepage \&q=como\%20se\%20da\%20la\%20electroforesis\&f=fal se

Sette, Rubens. Tratamiento de aguas residuales [En linea]. Canada: Reverte S. A, 1990 [Fecha de consulta: 27 septiembre 2017]. Disponible en:

https://books.google.com.pe/books?id=30etGjzPXywC\&printsec=frontcover\&hl=es\&source=gbs_ge_summ ary_r\&cad $=0 \# v=0$ nepage $\& q \& f=f a l s e$

TW201427692. Lin Yee-Shin; Chen Yu-Hung. "Biodegradable carrier with arbitrarily adjustable interface charges and particle sizes, a preparing method and a pharmaceutical composition of the same". 2014.

US4602989. Culkin, Joseph. "Method and apparatus for determining the zeta potential of colloidal particles". 1986.

US5022972. David Agoston; David Ne Kenez Maria; Racz Istvan. Process for measuring and determining zeta potential in a laminary flowing medium for practical purposes. 1991

US6051124. Hidemitsu, Aoki. “Zeta-potential determining apparatus”. 2000.

US5280250. Jayaweera Palitha; Hettiarachchi Samson. Method and apparatus for measuring zeta potential of a substance at high temperature. 1994.

US2014303048. Kakadjian Sarkis; Zamora, Frank; Veldman Raynard; Van Petegen Ronald. "Zeta potential modifiers to decrease the residual oil saturation". 2014

US3411356. Moser, B. y Wiech, E. R. "Zeta Potential Flowmeter". 1968

US2008264795. Sides Paul; Hoggard, James. "Apparatus and Method for Determining the Zeta Potential of Surfaces for the Measurement of Streaming Metrics Related Thereto". 2008. 